\title{
Thinking Carefully About Inclusiveness: Evidence from European Guilds
}

(accepted in the Journal of Institutional Economics, 12 Oct. 2020)

\author{
Sheilagh Ogilvie \\ All Souls College, Oxford
}

\begin{abstract}
Policy lessons are often drawn from the emergence of "inclusive" institutions in pre-modern Europe, which are held to have displaced "extractive" institutions and fostered economic growth. This paper analyzes the concept of inclusiveness using evidence on a historical institution that has been widely viewed as inclusive - the guild. It finds that we must differentiate between three types of inclusiveness: community, corporative, and societal. Community inclusiveness refers to the share of individuals involved in an institution's operations, corporative inclusiveness the share of political representation enjoyed by the institution itself, and societal inclusiveness the extent to which the institution enables full economic and political participation by everyone in society. We must also distinguish between general inclusiveness, which takes into account general-equilibrium effects, and partial inclusiveness, which assumes away such effects. Inclusiveness and extractiveness are not opposites in theory, and guilds show why certain types of inclusive institution are likely to behave in extractive ways. Finally, guilds alert us to trade-offs between inclusive economic institutions, inclusive political institutions, and inclusive growth. History does not imply abandoning the concept of inclusiveness, but rather thinking about it carefully.
\end{abstract}

Keywords: Guilds; inclusiveness; extractiveness; economic growth; economic history

\section{Introduction}

Why did northwest Europe experience faster economic growth than other world regions even before the Industrial Revolution? One influential explanation is that it developed institutions that were "inclusive" rather than "extractive". "Inclusive" institutions, according to this analysis, let everyone participate in politics and the economy. This creates good economic incentives for innovation and good political incentives for the rule of law, in turn fostering economic growth. "Extractive" institutions, by contrast, enable privileged groups to expropriate resources from the rest of society, undermining property rights and deterring 
innovation. Modern poor economies, the analysis concludes, will achieve prosperity if they establish inclusive institutions like those of pre-modern Europe.

The antithesis between inclusiveness and extractiveness raises both theoretical and historical questions. Inclusiveness, as it was originally proposed by Acemoglu and Robinson (2012), had much in common with concepts such as "generalized institutions" (Ogilvie 2005, 2007), "open-access orders" (North, Wallis, and Weingast 2009), and "general rules" (Johnson and Koyama 2019). But the ordinary-language definitions of inclusiveness that have diffused in the literature alert us to conceptual ambiguities, raising questions about who is included, what they are included in, whether inclusiveness should be assessed on a partial- or general-equilibrium basis, and what effect inclusiveness has on economic and political behaviour. "Inclusive" and "extractive" are not logical opposites, since the former designates what happens to economic agents, the latter what happens to economic resources. This leaves open the question of what mechanisms might link inclusive treatment of people with nonextractive treatment of resources, and how they affect wider economic performance.

This paper addresses these questions by analyzing a historical institution widely viewed as inclusive - the guild. Guilds regarded themselves as inclusive. The Paris hosiers declared in 1268 that their privileges served "the good and profit of the craft and the commonality of the people", while the Middle Rhine bakers asserted in 1436 that their guild fostered "the utility of both rich and poor, all men" (Ogilvie 2019, pp. 1, 7). Contemporary political thinkers regarded guilds as inclusive, as when Bodin questioned in 1583 "whether a commonwealth can dispense with associations and guilds" (Rosser 2015, p. 11). Later historians believe guilds were politically inclusive, as when Kemble argued that "[i]n the times of densest seignorial darkness [the guilds] offered a noble resistance to episcopal and baronial tyranny, and formed the nursing-cradles of popular liberty" (Ogilvie 2019, p. 549).

Modern scholars have also portrayed guilds as inclusive institutions. One view postulates that guilds offered an inclusive alternative to non-inclusive "clans" or extended families (Greif and Tabellini 2010, 2017; De la Croix, Doepke, and Mokyr 2018). A second maintains that guilds nurtured inclusiveness by encompassing a majority of the population in their membership (Richardson 2004; Prak 2018; Stasavage 2017; Prak et al. 2020). A third hypothesizes that merchant guilds transformed non-inclusive feudal societies into inclusive bourgeois polities (Stasavage 2014; Angelucci, Meraglia and Voigtländer 2017). A final view argues that craft guilds initiated European democratic governance (Kluge 2007; Van Bavel 2010). 
This paper uses the historical exemplar of the guild as a basis for clarifying the concept of inclusive institutions. Empirically, it investigates inclusiveness using the Ogilvie Guilds Databases, a compilation of 17,384 observations of guilds, covering over 400 occupations in 23 European societies from the late tenth to the late nineteenth century. ${ }^{1}$ These databases are an order of magnitude larger than any other compilation of evidence on guilds, and their collection, sources, typology, periodization, and geographical coverage are discussed in detail in Ogilvie (2019, pp. 24-31).

Theoretically, this paper uses the specific historical institution of the guild to tease out a number of general conceptual distinctions about inclusiveness. It finds that we must distinguish between three types of inclusiveness - community, corporative, and societal. "Community inclusiveness" refers to whether an institution includes many individuals in its own operations, "corporative inclusiveness" to whether an institution is itself included in economic and political decision-making, and "societal inclusiveness" to whether a particular institution lets everyone in the society make free economic and political choices. Guilds also show the difference between "partial inclusiveness" (focusing on each institution separately, holding others constant) and "general inclusiveness" (analyzing how a particular institution affects society at large). Guilds clarify why inclusiveness does not necessarily preclude extractiveness, and alert us to painful trade-offs between inclusive economic institutions, inclusive political institutions, and inclusive growth.

\section{What Is a Guild?}

A guild is an association of people who share certain interests and wish to pursue common purposes. Historically, most guilds organized themselves around economic interests (Ogilvie 2014b, 2019). A guild had legal privileges giving its members the exclusive right to practise a particular occupation in a particular town or region, control entry to the guild, govern the activities of members, and regulate markets for their inputs and outputs - and thus also to modify the activities of people who were not members of the guild.

Guilds varied hugely across occupations, sectors, societies, and eras. One key distinction was between merchant and craft guilds. Merchant guilds were organized mainly by wealthy wholesalers with interests in trade and finance (Ogilvie 2011, pp. 19-38). Craft guilds, by contrast, were organized mainly by modest craftsmen and retailers providing goods

\footnotetext{
${ }^{1}$ Files are downloadable from http://www.econ.cam.ac.uk/people/faculty/sco2/projects/ogilvie-guilds-databases.
} 
and services directly to customers (Ogilvie 2019, pp. 9-11). Craft guilds were more numerous, their members less wealthy, and their interests more local, sparking the latemedieval "guild struggles" between craftsmen and merchants analyzed below. "Umbrella guilds" combining merchants and craftsmen in a particular line of business - e.g. wool or silk textiles - existed widely in Italy, where they suffered from internal divisions diluting their inclusiveness.

Guilds were widespread across Europe for nearly 900 years, from the late tenth to the late nineteenth century. Merchant guilds appear in the documentary sources for European societies from c. 1000 onwards, followed slightly later by craft guilds. Between c. 1100 and c. 1500 , most moderately remunerative crafts and services in European towns - and some rural regions - were organized into guilds. After 1500, guilds gradually weakened in the northwest corner of Europe, especially England and the Dutch Republic (for detailed discussion of multiple measures of guild strength, see Ogilvie 2019, pp. 512-59). But in central, eastern-central, Nordic and Iberian Europe, guilds got stronger after 1500 by allying with absolutist rulers and expanding into new sectors such as export-oriented protoindustries. France abolished its guilds in 1791, and exported guild abolition during the Napoleonic period to some German territories, Flanders, the Northern Netherlands, Switzerland, and northern Italy. But in many other German territories, the Austrian Habsburg lands, Iberia, and Scandinavia, guilds survived well into the nineteenth century. The last European guilds were not abolished until 1883 (Ogilvie 2019, pp. 533-6).

\section{Was the Guild an Inclusive Replacement for the Clan?}

Guilds in Europe are sometimes seen as inclusive because, it is argued, they provided an alternative to "clans" or extended families in non-European societies such as China (Greif and Tabellini 2010, 2017; De la Croix, Doepke and Mokyr 2018). In terms of the typology established above, guilds displayed greater "community inclusiveness" than clans, because they included a larger number of people in their operations, giving them entitlements to operate businesses by admitting them as apprentices and masters.

This theory, however, is not well supported by historical evidence. While the strength of extended family networks exists on a continuum, and Europe lacked "clans" in the Chinese sense (Shiue 2017), Italy, Iberia, southern France, Poland, Slovakia, Hungary, Romania, Greece and the Balkans all had strong extended family systems in which kinship was economically important (Hajnal 1983; Dennison and Ogilvie 2014). Most of these societies 
also had strong guilds (Ogilvie 2019, pp. 555-9). Guilds thus did not substitute for strong extended families, but co-existed with them.

In nuclear- and extended-family zones of Europe alike, guilds favoured kin of existing guild members (Ogilvie 2019, 111-6). Some gave precedence to members' relatives in deciding whom to admit to apprenticeship, journeymanship or mastership. Others exempted members' relatives from admission requirements such as apprenticeship or examination. And most charged members' relatives lower admission fees. In a sample of 245 guilds in eight European societies between 1233 and 1850, sons of existing masters paid admission fees that were just $43 \%$ of those charged to other local applicants (Ogilvie 2019, pp. 111-2). The 60 guilds in the sample that were located in "clan" societies (Bulgaria, Italy, Spain) charged masters' sons just $25 \%$ of the fees paid by other locals, while the 185 guilds in nuclear-family societies (England, northern France, Germany, the Dutch Republic, and the Southern Netherlands) charged masters' sons $49 \%$ of the normal local fee. ${ }^{2}$ In setting entry barriers, it seems, guilds did not substitute for clans but collaborated with them.

Unsurprisingly, a non-trivial share of guild members were relatives of existing members. In a sample of 499 guilds in 11 European societies from 1375 to 1860, 37\% were sons of existing guild members (Ogilvie 2019, p. 111-4). In a smaller sample of 15 guilds in 7 societies between 1500 and 1850, 55\% were either sons or other male relatives of existing guild members (Ogilvie 2019, pp. 115). Guilds judiciously recruited non-relatives of existing members, both to fill niches vacated by high urban mortality and to collect the high fees charged to outsiders. Even so, they maintained higher "legacy" admissions than modern Ivy League universities, widely castigated as non-inclusive institutions perpetuating privilege in present-day America (Blumberg 2017).

That European guilds admitted some non-relatives of existing members might suggest that they were at least more inclusive than Chinese clans. But too little is known of Chinese economic history to make this statement with certainty. We lack quantitative evidence on occupational entry barriers erected by Chinese clans. At least some Chinese crafts and trades admitted entrants unrelated to existing practitioners (Morse 1909, p. 168; Burgess 1930, p. 75). But few figures are available. On the one hand, Gamble (1921, p. 168) found that not a single Peking craft or trade limited admission by kinship or place of origin and even central and south Chinese crafts were exclusive only if they "demand some particular skill, have special trade secrets, or whose work is especially remunerative”. Burgess (1928, pp. 84, 124,

\footnotetext{
${ }^{2}$ This difference is significant at the $99 \%$ level, and holds controlling for date of observation.
} 
129) found that just one of the 42 Peking guilds he analyzed, that of the porters, restricted admission to sons and brothers of guild members. On the other hand, Moll-Murata (2013, p. 234) found that the Jingdezhen potters' guild, established in 1674 by a migrant group, subsequently included just "24 surnames". But Europe also had migrant groups which formed guilds that restricted access by kinship. The Viennese chimney-sweeps' guild was established in 1644 by nine masters from the Ticino and the Grisons, and for the next two centuries limited admission to members of just 14 families (Ehmer 1997, p. 184). The Viennese chimney-sweeps' kin-based admission was extreme by European standards, as we know from the wider literature. But whether Jingdezhen or Peking were extreme or typical by Chinese standards cannot be known without more research.

We also lack evidence on how non-inclusive Chinese clans were. Chinese clans could be quite amorphous, tracing their origins to an apical ancestor who lived centuries in the past or was completely fictional (Burgess 1928, p. 71). Some encompassed thousands of individuals who were not close relatives. A clan of this sort was at least as inclusive as a European guild, whose membership numbered at most a few hundred (Ogilvie 2019, p. 13).

The historical findings thus do not support the idea that guilds manifested greater community inclusiveness than clans. European guilds discriminated in favour of members' relatives, and did so even more in clan-based than nuclear-family-based societies. Available studies show that, at least in Peking, most Chinese occupations did not limit entry by kinship. We lack evidence to conclude that Chinese clans were less inclusive than European guilds.

\section{Did Guilds Include a Majority of the Population?}

A second hypothesis is that guilds were inclusive institutions because a majority of people were guild members (Richardson 2004; Prak 2018; Stasavage 2017; Prak et al. 2020). The evidence casts doubt on this idea.

A guild required membership from anyone who wanted to practise "its" occupation, and then limited admission (Ogilvie 2019, pp. 83-171). Guilds excluded many groups on identity grounds: almost all women and Jews; men without town citizenship rights; ethnic, religious and linguistic minorities; those with serf, slave or bastard ancestors. Guilds erected economic barriers, excluding practitioners of other occupations, those with insufficient property, migrants who could not get citizenship rights, and anyone who could not afford the many fees and charges. Many guilds, as we have seen, favoured relatives of existing members. Some excluded sons of "untouchables" such as skinners, tanners, bailiffs, 
executioners, millers, or linen-weavers (Stuart 1999). And many imposed catch-all clauses requiring good reputation, honourable status, or acceptability to existing members. In these ways, guilds were the opposite of inclusive.

Not all dimensions of guilds exclusiveness can be fully quantified, but available evidence shows that guilds excluded large swathes of the population. Half the population was excluded by definition. Almost no guilds - well below 1\% - admitted females to mastership (Ogilvie 2019, p. 236). Most only let women practise guilded occupations under a male member's license; even masters' wives and widows were only allowed to work subject to numerous conditions and restrictions. Females outside guild masters' households were barred completely. As far as women were concerned, guilds were not inclusive (Ogilvie 2019, pp. 232-306).

The vast majority of men were also excluded, because they lived outside towns. A few guilds had rural members, but the great majority were exclusively urban (Ogilvie 2019, pp. 91-3). The share of the European population living in towns of over 5,000 inhabitants was 6$8 \%$ in $1000,10 \%$ in $1300,11.4 \%$ in 1700 , and $12.4 \%$ in 1800 (Malanima 2010). So around $90 \%$ of European males were excluded from guilds because they were rural.

Even if you were an urban male, to join a guild you had to buy or inherit town citizenship rights. Towns did admit outsiders, for the same reasons guilds did - to fill niches vacated by high urban mortality and reap hefty fees from immigrants. Montbéliard charged a citizenship fee higher than a full year's journeyman's wages in 1603, rising to eight years in 1748 (Ogilvie 2019, p. 98). Many towns also required citizenship applicants to prove legitimate birth, majority religion, acceptable language and ethnicity, freedom from serfdom, minimum wealth, honourable parentage, and good reputation. Between 1584 and 1614, Berne rejected over $40 \%$ of citizenship applications, discriminating markedly against poorer candidates (Ogilvie 2019, p. 98). Such barriers meant that less than $39 \%$ of urban householders in premodern Europe held town citizenship (Ogilvie 2019, p. 99). And urban citizenship was usually necessary - though not sufficient - for guild membership.

Guilds themselves charged non-trivial admission fees. In a sample of 1,102 guilds in 7 European societies between 1233 and 1809, the average mastership fee was equivalent to 276 day's wages for a labourer - over a year's earnings at full employment (Ogilvie 2019, p. 122). Most guilds also levied money for masterpieces, examinations, entry feasts, gifts, bribes, fraternity fees, and other miscellaneous charges. In sixteenth-century Ghent these added $25-60 \%$ to the cost of admission, and in seventeenth-century Paris they were 
equivalent to 750 days' wages for a journeyman grocer (Ogilvie 2019, p. 125). Guilds were thus "inclusive" only for those with a financial cushion.

Even if someone was male, urban, a town citizen, and reasonably well-off, a guild could reject him on grounds of religion, language, skin colour, age, marital status, sexual history, serf or slave ancestry, illegitimate birth, premarital conception, or "dishonourable" parentage (Stuart 1999). Many guilds made admission dependent on the liking of existing guild members - a probationary period, a reputation certificate, personal sponsorship, collective vote, or ill-defined "favour". This was a binding constraint, as recognized by Wolfgang Vincentz who in 1553 prolonged his journeyman travels a second time because he did not know "who among the Breslau masters would on this occasion be unfavourable towards me" (Ogilvie 2019, p. 132). If all other entry barriers failed, a guild could usually devise a way of keeping someone out.

The quantitative outcome reflects these barriers. Across 47 towns in 9 European countries between 1300 and 1800, guild masters comprised just $36 \%$ of household heads and $8 \%$ of inhabitants (Ogilvie 2019, pp. 14-5). In comparatively liberal cities such as early modern London, Nördlingen, Aachen, Augsburg, and Danzig, guild masters accounted for 50$80 \%$ of householders and $11-18 \%$ of inhabitants. But in exclusive ones like Vienna, Bayonne, Bordeaux, Montpellier, Nantes, Florence, Padua, Rome, Turin, Amsterdam, and Malmö, they comprised just $10-30 \%$ of householders and $2-7 \%$ of inhabitants.

Guilds thus excluded most people from their activities. Even among the $10 \%$ of the European population who lived in towns, only just over one-third of households included a guild member. Guilds were neither able nor willing to offer economic and political inclusion to a majority of the population. Their "community inclusiveness" was high in some cases, but quite modest on average.

\section{Did Guilds Increase Corporative Inclusiveness in Premodern Polities?}

It might still be argued that guilds were more inclusive than the alternatives. They typically displayed modest "community inclusiveness", but might have enhanced "corporative inclusiveness" by enfranchising hitherto politically excluded groups. Thus merchant guilds might increase corporative inclusiveness by diluting noble domination of town government, and craft guilds expand it further by diluting merchant domination.

The evidence supports this idea for some times and places. In the tenth to twelfth centuries, the emergence of merchant guilds broke open the monopoly of royal, noble, 
church, and patrician groups over town governments, widening political participation to wholesalers and financiers - at least those with guild membership (Stasavage 2014; Angelucci, Meraglia and Voigtländer 2017). Then, in the thirteenth- to fifteenth-century "guild wars", craft guilds in some towns broke the political dominance of merchants and old elites, securing representation for small-business owners - if they were guild members (Kluge 2007; Van Bavel 2010).

Where this happened, guilds could beget political regimes of greater corporative inclusiveness. But this did not engender greater societal inclusiveness. Once formed, merchant guilds often used their political sway to exclude craftsmen. After the "guild wars", craft guilds used political influence to exclude and repress weaker guilds, wage-workers, women, Jews, peasants, and competitors. Guilds themselves were increasingly dominated by oligarchies and hereditary privilege. Guilds used their corporative inclusiveness to open access for their own members but close access for others (Blockmans 1999, p. 58; Farr 2000, pp. 170-81; Lantschner 2015, p. 576; Van Steensel 2016, pp. 42-6; Ogilvie 2019, pp. 38-41).

These findings on guilds yield important insights. First, inclusiveness is not a zeroone variable: it exists on a spectrum. Although merchant guilds created greater corporative inclusiveness than feudal regimes, and craft guilds than mercantile ones, urban guild regimes still excluded most of society. Merchant guilds used politics to exclude craftsmen, and craft guilds used it to exclude everyone else. Many institutions act inclusively on some dimensions but exclusively on others. Even when guilds were less exclusive than alternatives, they were far from fully inclusive.

Second, we must distinguish partial from general inclusiveness. The growing power of guilds had two countervailing effects. It transferred political representation from traditional elites to guild members, increasing corporative inclusiveness. But it gave guilds power to reduce inclusiveness for wide swathes of society - peasants, women, labourers, Jews. The net effect was to reduce societal inclusiveness. Guilds' partial-equilibrium effect was to increase inclusiveness for their members, holding other factors constant. But their general-equilibrium effect was to reduce inclusiveness in society as a whole.

Third, an increase in community and corporative inclusiveness could reduce societal inclusiveness. Community and corporative inclusiveness made guilds more effective in securing their interests. But guilds benefited by excluding entry. Nobles and patricians had little interests in stopping women, migrants, labourers, and minorities from practising crafts and trades. This indifference created interstices within which marginal groups could earn a living. But guilded merchants and craftsmen viewed such groups as dangerous competitors, 
and used their own community and corporative inclusiveness to reduce societal inclusiveness for broader social strata (Ogilvie 2019, pp. 83-171, 232-306).

Institutions characterized by community and corporative inclusiveness have a bright side: they expand opportunities for the people they include and represent. But they also have a dark side: their very community and corporative inclusiveness gives them potent tools to limit opportunities in society more widely.

\section{Inclusiveness Versus Extractiveness - What Do Guilds Tell Us?}

What of the antithesis between inclusiveness and extractiveness? Inclusive means accommodating rather than blocking participation by people, while extractive means expropriating rather than creating resources. Theoretically, therefore, high inclusiveness among persons does not rule out high extractiveness towards resources. Empirically, many guilds that fostered inclusiveness with regard to their members also fostered extractiveness with regard to resources. Indeed, community and corporative inclusiveness could encourage and intensify extractive behaviour.

In pre-modern Europe, both less inclusive institutions (such as the princely state, the manorial system, or the ecclesiastical hierarchy) and more inclusive ones (such as guilds of merchants or craftsmen) behaved extractively (Ogilvie 1997, 1999, 2000; Ogilvie and Carus 2014; Johnson and Koyama 2019). Rulers, nobles, and churchmen used their institutional powers to extract resources from the economy and redistribute them to their own beneficiaries. So did guildsmen. Crown, nobility and church extracted resources by levying taxes, tithes, tolls, conscripts, and coerced labour. Guilds did so by limiting entry and manipulating markets.

Guild entry barriers were inherently extractive. In a non-guilded occupation, producers competed. A lower-cost producer could freely enter, capturing some customers by charging lower prices. This compelled existing producers to lower their prices to stay in business. A guild entry barrier enabled entrenched producers to exclude the entrant or make her pay for admission. This raised her production costs, reduced her ability to compete, and enabled guilds to charge customers higher prices. Entry barriers also increased internal cohesiveness, easing "tacit collusion" among guild members on prices and output (Ivaldi et al. 2003, pp. 12-18; Ogilvie 2019, pp. 519-27). Community inclusiveness thus facilitated guilds' extractiveness. 
Entry barriers enabled guilds to behave extractively by manipulating markets (Unwin 1908; Lipson 1915; Mickwitz 1936; La Force 1965; Ogilvie 2019, pp. 172-231). Most guilds limited supplies, since scarcity raised prices without open price-fixing. So guilds set output quotas, limited working time, and limited each workshop's raw materials, equipment and workforce. Available evidence suggests that a successful guild could limit output to $33-67 \%$ of the technically feasible level, creating sufficient scarcity to raise prices (Ogilvie 2019, pp. 220-4).

Prices certainly rose when guilds enjoyed market power and fell when they lost it (Ogilvie 2019, p. 220-2). In fourteenth-century London, the fishmongers' guild imposed prices 54\% higher than non-guilded competitors. In 1618, Coburg cartwrights and ploughsmiths were forced to join guilds: cart and plough prices immediately increased. In eighteenth-century Bordeaux, guild-free enclaves expanded, lowering prices throughout the city. In 1828, the Swiss the canton of Freyburg described how, since the abolition of 38 years earlier, industrial activity "has not only noticeably proliferated, but also made noticeable progress in performance and products, and prices have become more moderate and cheaper". A compilation of all available quantitative observations comparing guild with non-guild prices suggests that guilds increased prices $47 \%$ above the competitive rate (Ogilvie 2019, pp. 220-4). These guild price rises are on the high end of the spectrum compared to modern cartels (Connor 2014; Ivaldi et al. 2017), almost certainly because guilds were legally entitled to act as cartels - an outgrowth of their corporative inclusion in politics.

Guilds also behaved extractively in markets for inputs. Many depressed prices for raw materials by imposing price ceilings, claiming prior rights to purchase, and banning sales to outsiders (Mickwitz 1936; La Force 1965; Poni 1991; Kluge 2007; Ammannati 2014; Ogilvie 2019). Almost all guilds intervened in labour markets to reduce the wages their members had to pay employees (La Force 1965; Kaplan 1986; Kisch 1989; Caracausi 2011; Horn 2015; Ogilvie 2019). Guilds forbade masters to compete for workers, capped those workers' wages, and made it hard for employees to change jobs. One German guild even forbade its members to offer workers hot drinks in the evening, as it would compel other masters to offer the same (Ogilvie 2019, p. 190). Some guilds went so far as to allocate journeymen to masters centrally, preventing them from shopping around. This was common in France, where in 1731 a Bristol tailor who was swept up in a journeymen's riot against the practice remarked in astonishment that "in England there was no guild labour-allocation officer, the journeymen being free to take employment with the master whom they find most appropriate" (Ogilvie 
2019, p. 191). Guilds used their political influence - a by-product of corporative inclusiveness - to break strikes and punish workers who demanded better conditions.

Guilds also behaved extractively by engaging in rent-seeking. In exchange for entitlements to restrict entry and manipulate markets, guilds offered favours to political elites. A compilation of 732 observations of 16 European economies from the eleventh to the nineteenth century shows guilds obtaining economic privileges by offering political elites cash payments, a share in guild revenues, ad hoc fiscal donations, regular taxes, low-interest loans, help in tax collection, regulatory assistance, military contributions, and political backing (Ogilvie 2019, pp. 46-69). Such rent-seeking was costly. In one analysis of 43 guilds in seven medieval and early modern European economies, an average guild's annual pecuniary expenditures on lobbying amounted to 1,759 days' wages for a guild master. To this must be added the non-pecuniary benefits guilds offered rulers and the time spent petitioning, negotiating, litigating, and demonstrating (Ogilvie 2019, pp. 70-7).

Such behaviour was extractive in two ways. First, it extracted resources from other groups to transfer to guild members. By excluding non-members from producing and limiting entry of new members, guilds compelled would-be entrants to shift to activities where they were less productive and earned lower incomes. By limiting competition in input markets, guilds extracted income from employees and upstream producers and transferred it to guild members. By limiting supplies and increasing prices, guilds extracted income from customers and redistributed it to guild members. These extractive activities reduced the welfare of nonguild members, as revealed by the complaints, conflict, and behavioural distortions it evoked among customers, workers, suppliers, and competitors (for detailed quantitative and qualitative analysis, see Ogilvie 2019, chs. 3-5).

Second, guilds extracted resources from the economy as a whole. When a guild artificially fixed prices or limited output to procure cartel profits, some quantity of output that customers valued more than it would cost to produce was no longer produced and exchanged. By acting as a cartel, a guild reduced aggregate production and consumption in the economy. Additionally, guild rent-seeking absorbed inputs without increasing production or consumption, reducing the resources available to the economy (for detailed quantitative estimates of the minimal cost of guild rent-seeking, see Ogilvie 2019, ch. 2).

Analysing guilds shows concretely how inclusive institutions could harm economic growth. A guild's community and corporative inclusiveness created incentives for its members to allocate their efforts to cartelistic economic behaviour and rent-seeking political behaviour. It motivated non-guild-members to allocate efforts to evading guild cartels and 
lobbying against guild privileges. Guilds motivated people to redistribute existing resources, not produce new ones. They were extractive because they created incentives to allocate resources to zero-sum rather than positive-sum activities.

Were guilds extractive because they were not inclusive enough? The answer is no. Guilds show clearly that high community and corporative inclusiveness could co-exist with high extractiveness. On average, as we saw above, guilds' community inclusiveness was modest, since they included only $36 \%$ of urban householders. But guilds in some places, such as Nördlingen, Rome, Cuenca, Coventry, or Augsburg, displayed higher community inclusiveness, incorporating $60-80 \%$ of householders. In such towns, guilds also often displayed corporative inclusiveness via political representation. Yet they nonetheless behaved extractively. Each guild, even the most inclusive, erected entry barriers against members of other guilds, set artificially high prices, restricted output, depressed workers' wages, blocked disruptive innovations, and engaged in rent-seeking. Each guild acted as a mini-cartel, transferring resources from others to its own members and inflicting deadweight losses on the economy by raising prices and limiting supplies. Even the most inclusive guilds engaged in lobbying, lawsuits, prosecutions, and violent action against encroachments by other guilds, workers who demanded higher wages, and black-market interlopers. Such rent-seeking consumed resources unproductively, reducing the amount produced, consumed, and exchanged in the economy. Nothing prevented a highly inclusive guild system from also being highly extractive.

But perhaps guilds at least reduced the overall quantity of extraction? Not at all. The emergence of guild extractiveness in late-medieval Europe did not displace the extractiveness of rulers, nobles, the church, or merchants. Rather, guilds added another layer of extractive activities on top of those already pursued by other extractive institutions. A shift to greater community and corporative inclusiveness, as guild history shows, does not imply a move to lower extractiveness.

The evidence on guilds holds an even bleaker lesson. Community and corporative inclusiveness not only co-existed with extractiveness but often reinforced it. Precisely guilds' community and corporative inclusiveness could make them more effective in behaving extractively, by increasing their economies of scale in monitoring and enforcement, their social legitimacy, and their political influence.

Moreover, the reason guilds existed so widely for so many centuries, despite the harm they caused, was that they often collaborated with rulers, nobles, lords of the church, and urban patriciates. These elites were the beneficiaries of institutions - the princely state, the 
feudal system, the established church, the privileged town - which, though not wholly noninclusive, were less inclusive than the guild. Guilds provided an organizational mechanism for groups of businessmen to lobby these political elites for market privileges that profited guild members. Guilds then redirected a share of the profits to political elites in the form of gifts, bribes, taxes, favourable loans, regulatory cooperation, military services, and political support. Neither guilds nor political elites could have extracted these resources on their own. The relationship between guilds and governments varied across Europe and increasingly diverged even after 1500. In the Low Countries and England, political authorities gradually ceased to enforce guild privileges. But in "corporatist-absolutist" states such as Spain, Austria, Scandinavia, and many German territories, political elites increasingly profited from their particularistic bargain with guilds long past 1800 (Ogilvie 2014b, 2019). Across vast swathes of pre-modern Europe, therefore, the more inclusive institution of the guild collaborated with the less inclusive institutions that dominated politics, to extract resources for their own beneficiaries, at the expense of everyone else (Ogilvie 1999, 2019; Johnson and Koyama 2019).

The mutually reinforcing exchange of favours between guilds and political elites in pre-modern European societies prefigured a pattern widespread in modern developing economies. Political elites grant entry barriers and market privileges to groups of existing producers. This enhances these groups' community and corporative inclusiveness, but also grants them market power, helping them extract cartel profits from consumers. Part of these profits are then shared with political elites in return for official enforcement of market privileges. Payments from privileged businessmen increase government and elite revenues, but distort resource allocation and stifle growth. Developing economies, historical or modern, can find themselves lastingly burdened with institutions that use community and corporative inclusiveness to facilitate extraction by businessmen and politicians, who therefore cooperate to keep such institutions in being (Auriol and Warlters 2005). Institutions characterized by community and corporative inclusiveness can systematically collaborate with institutions that are profoundly non-inclusive, reinforcing the extractive capacities of both. As guilds show, we cannot understand the delicate balance of power between state and society without scrutinizing intermediating institutions that combine strong community and corporative inclusiveness with powerful extractiveness (Ogilvie 2019; Acemoglu and Robinson 2019). 


\section{Do Inclusive Institutions Lead to Inclusive Economic Growth?}

Highly inclusive guilds, we have seen, often engaged in activities that can only be described as highly extractive. They expropriated resources from other social groups to redistribute to their own members; they imposed deadweight losses on the whole economy via their cartelistic activities; and they consumed resources in rent-seeking. The historical evidence on guilds suggests that the extractive behaviour often pursued by these inclusive institutions also stifled economic growth.

Guild strength varied widely across European societies according to multiple measures, including guilds' numbers, internal cohesion, relations with merchants, political privileges, town-country relations, and competition from jurisdictional enclaves (Ogilvie 2019, pp. 512-54). Taking all these dimensions into account, the strongest guilds were found in Germany, Iberia, Scandinavia, and Austria-Hungary. Guilds of intermediate strength were found in Switzerland, France, and the German Rhineland. Italy also lay in this intermediate zone, partly because its export-oriented textile manufactures formed multi-occupational "umbrella guilds", whose inclusiveness (and extractiveness) were sapped by internal divisions. On nearly all measures, the weakest guilds were found in the Southern Netherlands (modern Belgium), the Dutch Republic, and England (Ogilvie 2019, pp. 555-9).

When guild strength is mapped against economic performance, it displays an inverse relationship (Ogilvie 2019, pp. 559-63). Strong guilds were found in poor and stagnant economies, weak guilds in rich and dynamic ones. The best estimates of per capita GDP between c. 1300 and c. 1850 show higher levels and faster growth in societies with comparatively weak guilds: Flanders, Holland, and England. Lower per capita GDP and slower growth was found in societies with the strongest guilds: Germany, Austria, Iberia, Scandinavia.

A similar inverse relationship prevailed between guild strength and population growth. Across 85 cities in the Low Countries, Switzerland, France, Germany, and northern Italy between 1000 and 1800, unsuccessful guild revolts had no effect on demographic growth, controlling for other town characteristics, but successful revolts giving guilds representation on town councils resulted in lower growth (Stasavage 2017). Among 282 cities in German-speaking Europe between 800 and 1800, likewise, population grew more slowly in those with greater council representation for guilds, with the negative effect of guilds intensifying over time (Wahl 2019). 
Of course, association does not imply causation. Many factors affect both guilds and growth. Cross-city analyses can control for some confounding factors, but more aggregative comparisons across regions or countries struggle to do so adequately. Guilds were not the only institution to harm growth. Central Europe, Iberia, and Scandinavia suffered from other extractive institutions: militaristic states, rapacious landlords, monopolistic merchants, coercive towns, predatory churchmen, and stagnant villages (Ogilvie 1999, 2000; Ogilvie and Carus 2014). Guilds were just one component of a broader institutional framework in which political elites granted privileges to powerful groups who used them to extract benefits, harming the whole economy. Guilds mainly regulated manufacturing and trade, whereas agriculture accounted for the vast majority of the pre-modern economy, so feudal landlords and peasant communes mattered more. But although many institutions impaired economic performance, there is much evidence - as we have seen - that guilds were one of them. Community and corporative inclusiveness could facilitate extraction and stifle innovation.

Even if guilds harmed economic performance, perhaps they favoured equality, and thus gave rise to "inclusive growth", in the sense that any benefits of development reached the entire population, including its most vulnerable members? Guilds certainly aspired to maintain equality internally. Many guilds forbade their members to keep more than one workshop, employ more than a specified number of workers, produce above a particular output quota, work longer hours, sub-contract to others, or advertise their wares. Guilds often prohibited innovations that might enable one member to entice customers away from his fellows.

Such rules may indeed have reduced inequality inside some guilds. On the other hand, micro-studies of specific guilds show powerful groups gaining control of internal decisionmaking and used guild rules to benefit themselves, intensifying internal inequality (Poni 1989; Ogilvie 1997; Cerutti 2012). Many guilds were dominated by rich oligarchies.

Moreover, in achieving inclusive growth, equality in the wider society matters far more than equality inside occupations. As we have seen, guilds excluded wide swathes of would-be producers, especially women, minorities, migrants, and the poor, limiting guild membership to just over one urban household head in three. Guilds also enabled their members to overcharge customers and underpay employees. This inevitably widened the gap between the privileged guild masters and the larger population of outsiders, customers, and workers, which included the most vulnerable members of society (Ogilvie 1997, 2004, 2019).

Quantitative analyses of the relationship between societal equality and guilds are still in their infancy. But a pioneering study of 297 German towns between 1300 and 1850 found 
that, controlling for other urban characteristics, stronger guilds were associated with higher inequality (Schaff 2018). This is not surprising, given the politically sanctioned market power that guilds created for their members. A study of eight OECD countries in the early twentyfirst century found that market power, by driving up prices of goods and services, increases the wealth of the richest $10 \%$ of households by $10-24 \%$; this implies that public action to reduce market power, by enhancing enforcement of competition law and reducing politically sanctioned entry barriers, can substantially reduce inequality (Ennis and Kim 2017).

Where pre-modern European guilds were strong enough to enforce their market power, they almost certainly increased societal inequality, because the benefits to guild members were eclipsed by the harm to the less well-off. These findings on guilds yield a further analytical lesson for understanding inclusiveness. Institutions characterized by greater community and corporative inclusiveness can actually sap "inclusive growth". This is because such institutions extract profits for their members at the expense of outsiders and the wider economy. They prevent the benefits of economic development from reaching the entire population and often deny them to the most vulnerable.

\section{What Do We Mean by Inclusive Societies?}

A final lesson from the historical institution of the guild is that we need to be clear about what we mean by inclusive societies. Is the goal inclusive economic growth, inclusive economic institutions, or inclusive political participation?

Inclusive economic growth sounds like an unalloyed good. Who could object to achieving economic development whose benefits extend to the whole population, including its most vulnerable members? But this alluring goal raises tough questions. Does inclusive growth imply aiming to achieve complete economic equality? In some ethical systems, equality is an objective in itself. But we also need economic growth, in order to generate the resources needed to alleviate poverty and improve opportunity for the most vulnerable. And we know equality interacts with growth. Higher equality improves people's capacities to do things that fuel growth - work, save, educate, and innovate. But higher inequality also creates incentives for aspirational groups to work, save, educate, and innovate - generating growth for redistribution. In principle, some rise in inequality may be desirable if it motivates economic activity that increase incomes for everyone in society, including the most vulnerable. What magnitude of trade-off are we willing to tolerate between growth and 
equality? Who decides on the desired combination of growth and equality? And, having decided upon the desired level of each, how do we achieve it?

Inclusive economic institutions are sometimes proposed as the best way to achieve inclusive growth. But this concept also raises questions. What is it about inclusive institutions that might be good for economic growth? Community and corporative inclusiveness, as we have seen, can increase an institution's capacity for extractiveness, harming economic growth. Institutions must be characterized by societal inclusiveness, enabling all individuals in society to participate fully in economic and political decision-making. This has led some scholars to define inclusive economic institutions as consisting in open-access, competitive markets with no barriers to entry (North, Wallis, and Weingast 2009; Acemoglu and Robinson 2012). History suggests, however, that although competitive markets are required for economies to grow, impartial public-order institutions are necessary for such markets to function (Ogilvie and Carus 2014; Acemoglu and Robinson 2019; Johnson and Koyama 2019). Markets need supportive institutions to guarantee property rights, enforce contracts, and solve other market failures such as monopolies, public goods, externalities, agency problems, and information asymmetries. What kind of institutions are best for supporting markets?

Inclusive political institutions might seem the answer. But what characterizes politically inclusive institutions? One widely held idea, as we have seen, is that they consist of corporative and communitarian institutions such as guilds and communities (Putnam et al. 1993; Greif 2006; Rajan 2019). The problem with such institutions, as shown by the historical evidence on guilds, is that they have a dark side. They may encourage beneficial collective action, albeit less than is often assumed in the case of guilds and village communes (Ogilvie 1997, 1999; Dennison and Ogilvie 2007; Ogilvie 2019, chs. 6-8). But communitarian and corporative institutions may also facilitate collective action that is both exclusive and extractive (Tullock 1975; Olson 1971, 1982). This emerges clearly from the entry barriers, market manipulation, and rent-seeking practised by guilds (Ogilvie 1997, 1999, 2019).

A widely emphasized alternative is to focus on societal rather than community or corporative inclusiveness, and define inclusive political institutions as democratic ones. In principle, democratic institutions operate in such a way that all individuals in society can participate fully in political decision-making. But democracy suffers from practical difficulties which lead straight back to the question of inclusiveness. Transaction costs mean that individual voters find it expensive to inform themselves about issues and difficult to 
organize to achieve their ends. Consequently, democracy almost always operates by individuals delegating decisions to parties and interest-groups (Olson 1971, 1982; Tullock 1975).

But well-organized interest-groups exhibit two forms of behaviour which can harm societal inclusiveness and economic growth - as the history of guilds shows. First, they have the incentive and capacity to engage in rent-seeking, leading to behaviour that is extractive, in the sense that it redistributes existing resources rather than creating new ones (Olson 1971). Second, such interest-groups have incentives that cause them to resist disruptive innovations (Ogilvie 2014, 2019). Yet the social capacity to undertake disruptive innovations in both technology and institutions is necessary for economies to grow, for growth to reach the most vulnerable, and for societies to adapt to exogenous challenges such as resource depletion, environmental damage, or climate change.

A major source of resistance to institutional innovation is the lack of what has been called a "political Coase theorem" (Acemoglu 2003; Ogilvie 2007). Institutional innovations, even if they benefit society as a whole, typically threaten at least some individuals and groups. Why does society not agree on what institutions would be best for economic growth, and then bargain over how the benefits should be distributed? The answer is that a group that holds (or obtains) some institutional power cannot make a credible commitment to bind its own future actions. The absence of a political Coase theorem means that institutional changes that would make the entire economy better off can easily be blocked by the inability of potential gainers from reform to promise credibly to reimburse the losers after institutional reform deprives the latter of power and resources.

Historically, inclusive political institutions have often found it difficult to undertake institutional reform. This is precisely because inclusive political institutions represent the views of the groups and institutions threatened with losses as a result of reform, and hence respond to these groups' interests, even when these do not serve the common weal. Less inclusive political institutions, by contrast, have a greater capacity to break a deadlock among entrenched interests and dictate a solution to the lack of a political Coase theorem. The abolition of serfdom in Prussia and Russia, for instance, was only achieved to the extent that the absolutist state - a profoundly non-inclusive political institution - made up for the lack of a political Coase theorem by mediating and enforcing a commitment for the gainers (serfs) to compensate the losers (noble landlords) (Ogilvie 2014a; Ogilvie and Carus 2014). The abolition of the French guilds in 1791, likewise, involved the Revolutionary state promising to compensate guildsmen for the loss of their valuable masterships, maintain entry barriers by 
requiring new producers to buy state licenses, and forbid collective action by newly emancipated journeymen (Pontet 1997). In other cases of guild abolition, as when Prussia declared "freedom of occupations" in 1806/1811, despotic states solved the absence of a political Coase theorem by steamrollering over community and corporate inclusiveness. The non-inclusive Prussian state found it much easier to undertake guild abolition than the inclusive states of the German south, where governments included guild representatives and were politically incapable of abolishing guilds until the 1860s (Ogilvie 1997, 2019).

Inclusive economic growth, history suggests, requires political institutions capable of doing two things. First, they must support open-access, competitive markets by guaranteeing property rights, enforcing contracts, and solving market failures. Second, they must address the lack of a political Coase theorem, enabling the institutional framework to reform itself and adapt to change. History suggests that a central challenge for future research is to analyze how we foster political institutions that perform both these services well. Sadly, there are painful trade-offs involved. Historically, inclusive economic growth has not always been best served by inclusive political institutions.

\section{Conclusion}

Where does this leave us in analyzing the institutional basis for inclusive societies? Historical lessons on institutions and growth are often drawn from the experience of Europe between 1500 and 1850, during which the north Atlantic economies pulled ahead of the rest of the world. This development is widely ascribed to the emergence of "inclusive" institutions which are held to have fostered growth by displacing "extractive" institutions. The term inclusiveness is now widely diffused in the literature and has attracted a penumbra of interpretations derived from its ordinary-language connotations. This paper has sought to restore clarity to the concept by examining rich evidence on a historical institution - the guild - which is widely viewed as inclusive because of its communitarian and corporative attributes.

A first lesson is the need to differentiate between community, corporative, and societal inclusiveness. The history of guilds shows that high levels of community and corporative inclusiveness, in the sense of a large proportion of people involved in the operations of an institution together with a substantial degree of political representation enjoyed by it, do not necessarily foster societal inclusiveness in the sense that the institution enables full economic and political participation by the whole population. Community and corporative inclusiveness 
enabled guilds to enforce entry barriers and manipulate markets, benefiting their own members but reducing economic and political options for outsiders.

The historical example of the guild also yields a second valuable insight. We must distinguish between general inclusiveness, which takes into account general-equilibrium effects, and partial inclusiveness, which assumes away such effects. Guilds sometimes succeeded in increasing partial inclusiveness by expanding their own economic influence and political representation, particularly during the late-medieval "guild wars". But they then used their augmented influence to reduce corporative and community inclusiveness for those excluded from the guild regime, typically the weakest and most vulnerable members of society. The general-equilibrium effect was to reduce inclusiveness in society at large.

A third lesson is that high inclusiveness does not imply low extractiveness. Inclusiveness and extractiveness are not opposites in theory, and guilds show why inclusive institutions are able and willing to behave extractively in practice. Guilds used their community and corporative inclusiveness to limit entry and manipulate markets. They extracted resources from other groups and transferred them to guild members. They also extracted resources from the economy at large by cartelistically restricting output and engaging in rent-seeking. This extractiveness was often facilitated, not diminished, by guilds' inclusiveness. Nor did guilds reduce the overall quantity of extraction, instead augmenting it by adding another set of extractive activities on top of those already pursued by other extractive institutions such as the princely state, the feudal nobility, and the church. Indeed, guilds collaborated with these other extractive institutions, securing their support and enforcement in return for a share of the rents obtained through guild entry barriers and market manipulations. Guilds provide unambiguous evidence that institutions characterized by community and corporative inclusiveness can engage in mutually supportive exchanges with non-inclusive institutions, reinforcing the extractive capacities of both.

Finally, the exemplar of the guild demonstrates the importance of discriminating between inclusive economic institutions, inclusive political institutions, and inclusive growth. Inclusive economic growth, in the sense of achieving development whose benefits reach the whole population including the most vulnerable, is clearly desirable. But it is not necessarily best achieved through economic institutions characterized by community and corporative inclusiveness. Inclusive growth requires an institutional framework characterized by societal inclusiveness, and this may require curbing community and corporative inclusiveness.

One component of such an institutional framework comprises open-access, competitive markets. But although markets are required for economies to grow, public-order 
institutions are needed for markets to function. This implies creating inclusive political institutions. These do not - as guild history suggests - consist in corporative and communitarian institutions. Democratic institutions appear a better solution, but these must be carefully designed to perform two key services. First, they must support open-access, competitive markets by guaranteeing property rights, enforcing contracts, and solving market failures. Second, they must address the lack of a political Coase theorem, providing credible commitments from gainers to losers that enable the institutional framework to reform itself and adapt to change.

History does not imply abandoning the idea of inclusiveness. But it does imply thinking about inclusiveness carefully. 


\section{References}

Acemoglu, D. (2003). "Why Not a Political Coase Theorem? Social Conflict, Commitment and Politics." Journal of Comparative Economics 31(4): 620-652.

Acemoglu, D. and Robinson, J. A. (2012). Why Nations Fail: the Origins of Power, Prosperity and Poverty. New York, Crown Publishers.

Acemoglu, D. and J. A. Robinson (2019). The Narrow Corridor: States, Societies, and the Fate of Liberty. New York, Penguin.

Ammannati, F. (2014). "Craft Guild Legislation and Woollen Production the Florentine Arte della Lana in the Fifteenth and Sixteenth Centuries." In: K. Davids and B. De Munck, eds., Innovation and Creativity in Late Medieval and Early Modern European Cities. Aldershot, Ashgate: 55-80.

Auriol, E. and Warlters, M. (2005). "Taxation Base in Developing Countries.” Journal of Public Economics 89(4): 625-646.

Blockmans, W. and Prevenier, W. (1999). The Promised Lands: the Low Countries under Burgundian Rule, 1369-1530. Philadelphia, PA, University of Pennsylvania Press.

Blumberg, J. (2017). “Harvard's Incoming Freshman Class is One-Third legacy - Here's Why That's a Problem." CNBC https://www.cnbc.com/2017/09/06/harvards-Incoming-Classis-One-Third-legacy.html( 9 Jun. 2017).

Burgess, J. S. (1930). "The Guilds and Trade Associations of China.” Annals of the American Academy of Political and Social Science 152: 72-80.

Caracausi, A. (2011). "The Just Wage in Early Modern Italy: a Reflection on Zaccia's De Salario seu Operariorum Mercede." International Review of Social History 56(Special issue): $107-124$.

Cerutti, S. (2012). Étrangers: étude d'une condition d'incertitude dans une société d'Ancien régime. Montrouge, Bayard.

Connor, J. M. (2014). "Price-Fixing Overcharges: Revised 3rd Edition (February 24, 2014)." SSRN Working Papers 2400780.

De la Croix, D., Doepke, M. and Mokyr, J. (2018). "Clans, Guilds, and Markets: Apprenticeship Institutions and Growth in the Pre-Industrial Economy." Quarterly Journal of Economics 133(1): $1-70$. 
Dennison, T. and Ogilvie, S. (2007). "Serfdom and Social Capital in Bohemia and Russia." Economic History Review 60(3): 513-544.

Dennison, T. and Ogilvie, S. (2014). "Does the European Marriage Pattern Explain Economic Growth?" Journal of Economic History 74(3): 651-693.

Dennison, T. and S. Ogilvie (2016). "Institutions, Demography, and Economic Growth.” Journal of Economic History 76(1): 205-217.

Ehmer, J. (1997). "Worlds of Mobility: Migration Patterns of Viennese Artisans in the 18th Century.” In: G. Crossick, ed., The Artisan and the European Town, 1500-1900. Hants. / Brookfield VT: 172-199.

Ennis, S. F. and Kim, Y. (2017). "Market Power and Wealth Distribution.” In: World Bank, ed., A Step Ahead: Competition Policy for Shared Prosperity and Inclusive Growth. Washington, DC, World Bank Group: 133-153.

Farr, J. R. (2000). Artisans in Europe, 1300-1914. Cambridge, Cambridge University Press. Gamble, S. D. (1921). Peking: a Social Survey. New York, George H. Doran.

Greif, A. (2006). Institutions and the Path to the Modern Economy: Lessons from Medieval Trade. Cambridge, Cambridge University Press.

Greif, A. and Tabellini, G. (2010). "Cultural and Institutional Bifurcation: China and Europe Compared." American Economic Review: Papers and Proceedings 100(2): 135-140. Greif, A. and Tabellini, G. (2017). "The Clan and the Corporation: Sustaining Cooperation in China and Europe." Journal of Comparative Economics 45(1).

Hajnal, J. (1983). “Two Kinds of Pre-Industrial Household Formation System.” In: R. Wall, J. Robin and P. Laslett, eds., Family Forms in Historic Europe. Cambridge, Cambridge University Press: 65-104.

Horn, J. (2015). Economic Development in Early Modern France: the Privilege of Liberty, 16501820. Cambridge, Cambridge University Press.

Ivaldi, M., Jenny, F. and Khimich, A. (2017). "Cartel Damages to the Economy: An Assessment for Developing Countries.” In: World Bank, ed., A Step Ahead: Competition Policy for Shared Prosperity and Inclusive Growth. Washington, DC, World Bank Group: 77-110. Ivaldi, M., Jullien, B., Rey, P., Seabright, P. and Tirole, J. (2003). "The Economics of Tacit Collusion.” Final Report for DG Competition, European Commission, March 2003. Johnson, N. D. and M. Koyama (2019). Persecution and Toleration: the Long Road to Religious 
Freedom. Cambridge, Cambridge University Press.

Kaplan, S. L. (1986). "Social Classification and Representation in the Corporate World of Eighteenth-Century France: Turgot's 'Carnival'.” In: S. L. Kaplan and C. J. Koepp, eds., Work in France: Representations, Meaning, Organization and Practice. Ithaca, NY, Cornell University Press: 176-226.

Kisch, H. (1989). From Domestic Manufacture to Industrial Revolution: the Case of the Rhineland Textile Districts. Oxford, Oxford University Press.

Kluge, A. (2007). Die Zünfte. Stuttgart, Franz Steiner.

La Force, J. C. (1965). The Development of the Spanish Textile Industry, 1750-1800. Berkeley / Los Angeles, University of California Press.

Lantschner, P. (2015). The Logic of Political Conflict in Medieval Cities: Italy and the Southern Low Countries, 1370-1440. Oxford, Oxford University Press.

Lipson, E. (1915). The Economic History of England, Vol. I: The Middle Ages. London. Malanima, P. (2010). “Urbanization.” In: S. Broadberry and K. H. O’Rourke, eds., The Cambridge Economic History of Modern Europe, Vol 1: 1700-1870. Cambridge, Cambridge University Press. 1: 235-263.

Mickwitz, G. (1936). Die Kartellfunktionen der Zünfte und ihre Bedeutung bei der Entstehung des Zunftwesens: eine Studie im spätantiker und mittelalterliche Wirtschaftsgeschichte. Helsingfors, Societas scientiarum Fennica.

Moll-Murata, C. (2013). "Guilds and Apprenticeship in China and Europe: the Jingdezhen and European Ceramics Industries.” In: M. R. Prak and J. L. Van Zanden, eds., Technology, Skills and the Pre-Modern Economy in the East and the West: Essays Dedicated to the Memory of S. R. Epstein. Leiden, Brill: 225-258.

Morse, H. B. (1909). The Gilds of China, with an Account of the Gild Merchant or Co-hong of Canton. Shanghai / London / New York, Kelly \& Wash Ltd. / Longmans / Green.

North, D. C., Wallis, J. J. and Weingast, B. R. (2009). Violence and Social Orders. A Conceptual Framework for Interpreting Recorded Human History. Cambridge, Cambridge University Press.

Ogilvie, S. (1997). State Corporatism and Proto-Industry: the Württemberg Black Forest, 15801797. Cambridge, Cambridge University Press.

Ogilvie, S. (1999). “The German State: a Non-Prussian View.” In: J. Brewer and E. Hellmuth, 
eds., Rethinking Leviathan: the Eighteenth-Century State in Britain and Germany. Oxford, Oxford University Press: 167-202.

Ogilvie, S. (2000). "The European Economy in the Eighteenth Century.” In: T. W. C. Blanning, ed., The Short Oxford History of Europe, Vol. XII: The Eighteenth Century: Europe 1688-1815. Oxford, Oxford University Press: 91-130.

Ogilvie, S. (2004). "How Does Social Capital Affect Women? Guilds and Communities in Early Modern Germany." American Historical Review 109(2): 325-359.

Ogilvie, S. (2005). "The Use and Abuse of Trust: the Deployment of Social Capital by Early Modern Guilds.” Jahrbuch für Wirtschaftsgeschichte 2005(1): 15-52.

Ogilvie, S. (2007). “ 'Whatever Is, Is Right'? Economic Institutions in Pre-Industrial Europe.” Economic History Review 60(4): 649-684.

Ogilvie, S. (2011). Institutions and European Trade: Merchant Guilds, 1000-1800. Cambridge, Cambridge University Press.

Ogilvie, S. (2014a). "Serfdom and the Institutional System in Early Modern Germany." In: S. Cavaciocchi, ed., Slavery and Serfdom in the European Economy from the 11th to the 18th Centuries. Florence, Firenze University Press: 33-58.

Ogilvie, S. (2014b). "The Economics of Guilds.” Journal of Economic Perspectives 28(4): 169192.

Ogilvie, S. (2019). The European Guilds: An Economic Analysis. Princeton, Princeton University Press.

Ogilvie, S. and Carus, A. W. (2014). "Institutions and Economic Growth in Historical Perspective.” In: S. Durlauf and P. Aghion, eds., Handbook of Economic Growth. Amsterdam, Elsevier. 2A: 405-514.

Olson, M. (1971). The Logic of Collective Action: Public Goods and the Theory of Groups. Cambridge, MA, Cambridge University Press.

Olson, M. (1982). The Rise and Decline of Nations: Economic Growth, Stagflation and Social Rigidities. New Haven, Yale University Press.

Poni, C. (1989). "Norms and Disputes: the Shoemakers' Guild in Eighteenth-Century Bologna." Past \& Present 123: 80-108.

Pontet, J. (1997). "Craftsmen and Revolution in Bordeaux.” In: G. Crossick, ed., The Artisan and the European Town, 1500-1900. Hants. / Brookfield VT: 116-130. 
Prak, M., Crowston, C. H., De Munck, B., Kissane, C., Minns, C., Schalk, R. and Wallis, P. (2020 online early). “Access to the Trade: Monopoly and Mobility in European Craft Guilds in the Seventeenth and Eighteenth Centuries." Journal of Social History: 1-32.

Prak, M. R. (2018). Citizens Without Nations: Urban Citizenship in Europe and the World, c.1000-1789. Cambridge, Cambridge University Press.

Putnam, R. D., Leonardi, R. and Nanetti, R. Y. (1993). Making Democracy Work: Civic Traditions in Modern Italy. Princeton, NJ, Princeton University Press.

Rajan, R. (2019). The Third Pillar: How Markets and the State Leave the Community Behind. New York, Penguin Press.

Richardson, G. (2004). “Guilds, Laws, and Markets for Manufactured Merchandise in LateMedieval England.” Explorations in Economic History 41(1): 1-25.

Rosser, G. (2015). The Art of Solidarity in the Middle Ages: Guilds in England 1250-1550. Oxford, Oxford University Press.

Saul, N. (2017). Lordship and Faith The English Gentry and the Parish Church in the Middle Ages. Oxford, Oxford University Press.

Schaff, F. (2018). “Economic Divergence and the 'Inequality Extraction Ratio': Early Modern Germany in a European Perspective.” M.Phil. thesis, University of Cambridge.

Shiue, C. H. (2017). "Human Capital and Fertility in Chinese Clans before Modern Growth." Journal of Economic Growth 22(4): 351-396.

Stasavage, D. (2014). "Was Weber Right? The Role of Urban Autonomy in Europe's Rise." American Political Science Review 108: 337-354.

Stasavage, D. (2017). "When Inclusive Institutions Failed: Lessons from the Democratic Revolutions of the Middle Ages.” New York University Working Papers January 2017. Stuart, K. (1999). Defiled Trades and Social Outcasts: Honor and Ritual Pollution in Early Modern Germany. Cambridge, Cambridge University Press.

Tullock, G. (1975). “Competing for Aid.” Public Choice 21: 41-51.

Unwin, G. (1908). The Gilds and Companies of London. London, Methuen.

Van Bavel, B. J. P. (2010). Manors and Markets: Economy and Society in the Low Countries, 500-1600. Oxford, Oxford University Press.

Van Steensel, A. (2016). "Guilds and Politics in Medieval Urban Europe. Towards a Comparative Institutional Analysis.” In: E. Jullien and M. Pauly, eds., Craftsmen and 
Guilds in the Medieval and Early Modern Periods. Stuttgart, Franz Steiner: 37-56.

Wahl, F. (2019). "Political Participation and Economic Development. Evidence from the Rise of Participative Political Institutions in the Late Medieval German Lands.” European Review of Economic History 23(2): 193-213. 